\title{
Rose thorn injury
}

\author{
Katarina Kieselova, Felicidade Santiago, Martinha Henrique
}

Department of Dermatology, Centro Hospitalar Leiria, Leiria, Portugal

\section{Correspondence to}

Dr Katarina Kieselova,

katarinakieselova@gmail.com

Accepted 16 August 2017

\section{DESCRIPTION}

A 71-year-old man, with a history of arterial hypertension, presented with a 4-month history of four painful progressively enlarging nodules on the dorsal aspect of the right hand. The patient reported that he had been pricked by a rose on the fourth finger approximately 3 weeks before the appearance of the first lesion on the site of the injury. On physical examination, we observed four erythematous nodules, $10-15 \mathrm{~mm}$ in diameter, in linear distribution extending from the hand proximally (figure 1). Two nodules presented superficial erosions with purulent secretion. No systemic symptoms were detected. Histopathology revealed epidermal hyperkeratosis and suppurative small granulomas with polymorphous dermal infiltrate and periodic acid-Schiff staining identified rare fungal spores (figure 2). Culture from the biopsy specimen was negative. Clinical presentation and histology were consistent with sporotrichosis, so the patient was given itraconazole $200 \mathrm{mg}$ daily. After 3 months of treatment, only a mild improvement was observed; therefore, the dose was escalated to $200 \mathrm{mg}$ twice daily during following 4 months with complete resolution of 3 lesions. The

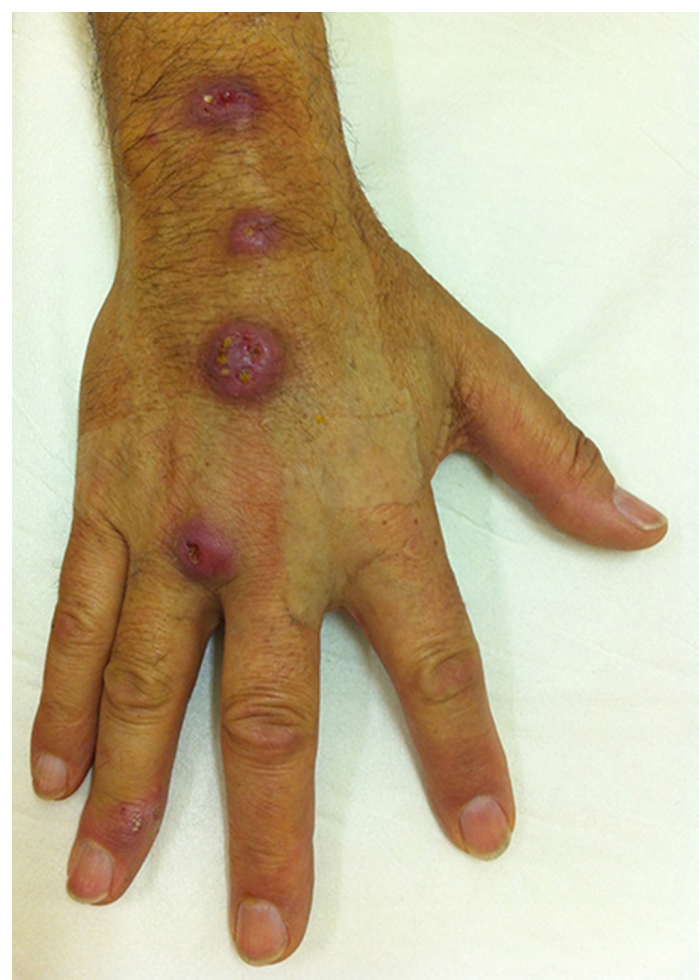

Figure 1 Four nodules on the dorsal aspect of the hand and forearm.

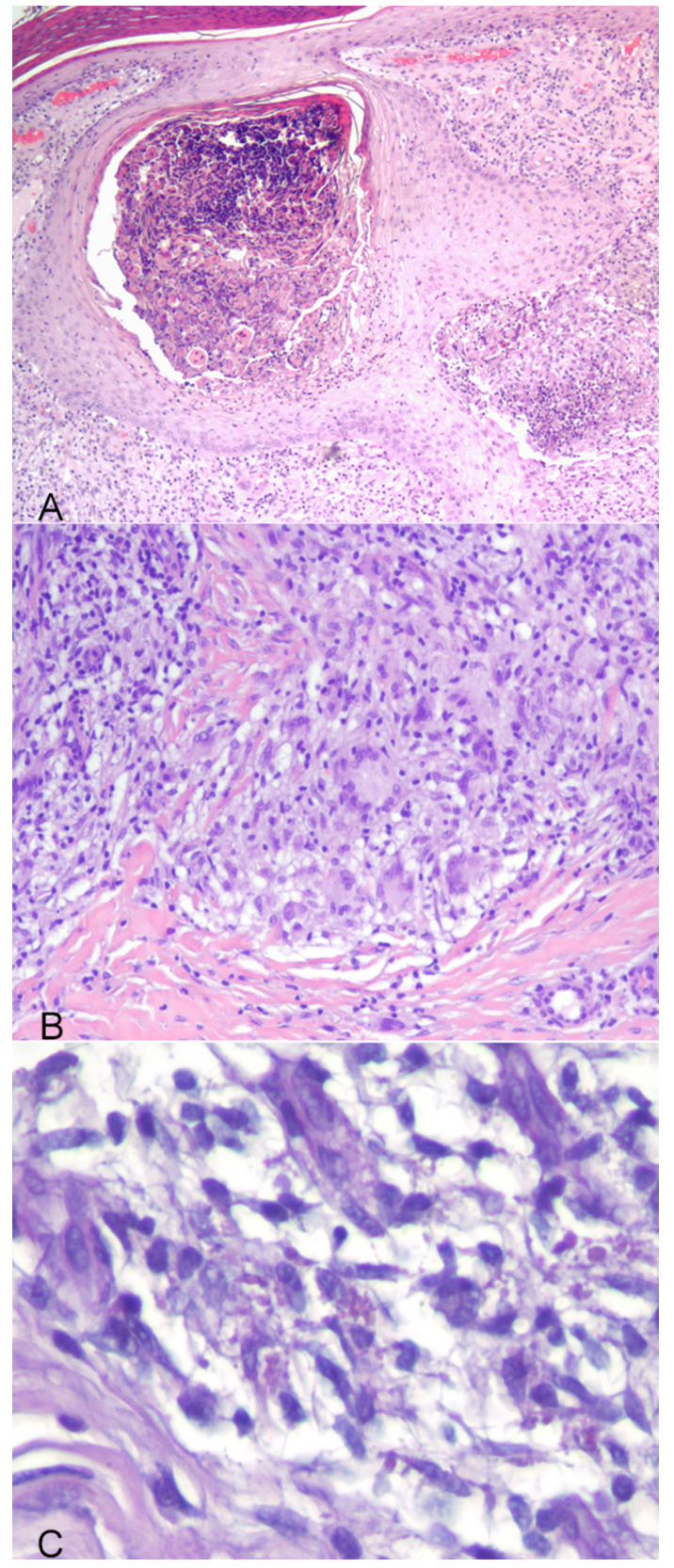

Figure 2 (A) Histology shows suppurative granulomas in dermis with overlying acanthotic epidermis and the areas of pseudoepitheliomatous hyperplasia (H\&E, $\times 100$ ). (B) Small granulomas composed of histiocytes, neutrophils and giant multinucleated cells are observed $(H \& E, \times 100)$. (C) Oval fungal spores and yeast-like forms may be seen (periodic acid-Schiff, $\times 400$ ).

fourth lesion was excised completely. There was no recurrence of the disease after 2-year follow-up.

Sporothrix schenckii, a saprophytic fungus, causes chronic infection, most frequently limited to skin 


\section{Learning points}

- Sporotrichosis is a rare chronic granulomatous mycotic infection caused by a bimorphic fungus Sporothrix schenckii. The most common form of sporotrichosis is a lymphocutaneous infection, which is caused by traumatic inoculation from contaminated plants, soil or through zoonotic transmission.

- The diagnosis of sporotrichosis is based on clinical presentation, epidemiological context together with laboratory studies (direct examination, culture and tissue histopathology). ${ }^{1}$

- Itraconazole $200 \mathrm{mg}$ daily for at least 3-6 months is the treatment of choice for the lymphocutaneous disease. Non-responders should be given itraconazole $200 \mathrm{mg}$ twice daily, terbinafine $500 \mathrm{mg}$ twice daily or saturated solution of potassium iodide if itraconazole is not available. Possible adverse side effects of the prolonged systemic antifungal treatment (headache, gastrointestinal, dermatological manifestation) or prolonged potassium iodide administration (endocrine, gastrointestinal and renal) require careful clinical and laboratory monitoring. ${ }^{1}$ and superficial lymphatics. Sporotrichosis presents as reddish papules at the site of inoculation, usually 3 weeks after the penetrating injury, with progression through the lymphatics forming multiple cutaneous nodules. ${ }^{1}$ Systemic sporotrichosis is rare and occurs from the haematogenous spread from the primary inoculation site or from the pulmonary sporotrichosis in immunocompromised patients. $^{2}$

Contributors All persons who meet authorship criteria are listed as authors. KK wrote the manuscript, reviewed by FS. KK performed the literature review. FS and $\mathrm{MH}$ made the diagnosis and performed the complete investigation and management of the patient. All authors approved the final version of manuscript.

Competing interests None declared.

Patient consent Obtained.

Provenance and peer review Not commissioned; externally peer reviewed.

(C) BMJ Publishing Group Ltd (unless otherwise stated in the text of the article) 2017. All rights reserved. No commercial use is permitted unless otherwise expressly granted.

\section{REFERENCES}

1 Barros MB, de Almeida Paes R, Schubach AO. Sporothrix schenckii and sporotrichosis. Clin Microbiol Rev 2011;24:633-54.

2 Mahajan VK. Sporotrichosis: an overview and therapeutic options. Dermatol Res Pract 2014;2014:1-13.

Copyright 2017 BMJ Publishing Group. All rights reserved. For permission to reuse any of this content visit

http://group.bmj.com/group/rights-licensing/permissions.

BMJ Case Report Fellows may re-use this article for personal use and teaching without any further permission.

Become a Fellow of BMJ Case Reports today and you can:

- Submit as many cases as you like

Enjoy fast sympathetic peer review and rapid publication of accepted articles

- Access all the published articles

Re-use any of the published material for personal use and teaching without further permission

For information on Institutional Fellowships contact consortiasales@bmjgroup.com

Visit casereports.bmj.com for more articles like this and to become a Fellow 